University of Nebraska - Lincoln

DigitalCommons@University of Nebraska - Lincoln

Faculty Publications: Department of Entomology

1994

\title{
Population Genetics and Gene Variation in Primary and Secondary Screwworm (Diptera : Calliphoridae)
}

David B. Taylor

University of Nebraska-Lincoln, dtaylor1@unl.edu

Richard D. Peterson II

University of Nebraska-Lincoln

Follow this and additional works at: https://digitalcommons.unl.edu/entomologyfacpub

Part of the Entomology Commons

Taylor, David B. and Peterson, Richard D. II, "Population Genetics and Gene Variation in Primary and Secondary Screwworm (Diptera : Calliphoridae)" (1994). Faculty Publications: Department of Entomology. 204.

https://digitalcommons.unl.edu/entomologyfacpub/204

This Article is brought to you for free and open access by the Entomology, Department of at DigitalCommons@University of Nebraska - Lincoln. It has been accepted for inclusion in Faculty Publications: Department of Entomology by an authorized administrator of DigitalCommons@University of Nebraska - Lincoln. 


\title{
Population Genetics and Gene Variation in Primary and Secondary Screwworm (Diptera: Calliphoridae)
}

\author{
DAVID B. TAYLOR AND RICHARD D. PETERSON II \\ Midwest Livestock Insects Research Laboratory, USDA-ARS, Department of Entomology, \\ University of Nebraska, Lincoln, NE 68583
}

\begin{abstract}
Ann. Entomol. Soc. Am. 87(5): 626-633 (1994)
ABSTRACT Allozyme variation in screwworm, Cochliomyia hominivorax (Coquerel), and secondary screwworm, C. macellaria (F.), populations from northwest Costa Rica was examined. Variability was observed in 11 of 13 enzyme loci and the frequency of the most common allele was $<0.95$ for 5 loci in screwworm. In secondary screwworm, 12 of 13 loci were variable and the frequency of the most common allele was $<0.95$ for 6 loci. Expected heterozygosities were 0.149 and 0.160 for screwworm and secondary screwworm, respectively. Goodness-of-fit statistics for Hardy-Weinberg equilibrium and Wrights $F$ statistics indicated that both species are panmictic with no evidence of population substructuring. Nei's genetic distances were $0.000-0.001$ for intraspecific comparisons and $0.899-0.916$ for interspecific comparisons. The data indicate a high level of gene flow between populations within each species.
\end{abstract}

KEY WORDS Cochliomyia hominivorax, C. macellaria, population genetics

SCREwworm, Cochliomyia hominivorax (Coquerel), is a serious pest of livestock throughout the Neotropical Region (Guimaraes et al. 1983, Snow et al. 1985, Krafsur et al. 1987, Rawlins \& Mansingh 1987). Before its eradication from North America (Graham 1985), screwworm ranged from the central United States to central Argentina and Chile (Dear 1985). Secondary screwworm, Cochliomyia macellaria $(\mathrm{F}$.), is similar morphologically to screwworm and ranges from southern Canada to Argentina and Chile (Hall 1948, Dear 1985). The two species were considered conspecific until Cushing \& Patton (1933) separated them by differences in the male genitalia. Although morphologically similar, the two species differ greatly in their biology. Screwworm is an obligate parasite of warm-blooded vertebrates. The female fly lays her eggs on the margin of a wound. Larvae enter the wound and feed on live tissue of the host (Laake et al. 1936). Screwworm larvae cannot complete their development in carrion (Brody \& Knipling 1943). Secondary screwworm is saprophagous, breeding primarily on carrion or decomposing meat (Hall 1948). Although secondary screwworm will oviposit on living hosts as a secondary agent of myiasis, the larvae normally feed on decomposing tissue or outside the wound (Knipling \& Travis 1937). Secondary screwworm is much more abundant in nature than screwworm. Laake et al. (1936) reported the ratio of screwworm to secondary screwworm to be 1:590 at wounds and 1:2427 at meat-baited fly traps.
Despite the economic importance of screwworm and the reliance on genetic techniques for its control and eradication, few studies have been published on the population genetics of this species. Bush \& Neck (1976) identified five variable enzyme loci in laboratory colonies of screwworm, but they did not examine any field populations. Richardson et al. (1982) indicated that significant allozyme polymorphism exists in screwworm and that the variation is concordant with the differentiation of reproductively isolated subpopulations. Unfortunately, these authors have not published any data in support of this statement. Whitten (1980) examined two allozyme loci in screwworms from a single population in Texas. Krafsur \& Whitten (1993) examined three allozyme loci in 11 populations from central Mexico. Krafsur \& Whitten concluded that the breeding structure of screwworm is that of a single, panmictic population. No studies on genetic variation in C. macellaria have been published.

The purposes of this study were to identify useful allozyme loci for studying genetic variation in screwworm, to develop a baseline for genetic variation in screwworm by examining several populations from a single region, and to determine the level of genetic differentiation between screwworm and secondary screwworm.

\section{Materials and Methods}

Specimens. Adults of both species were collected from three locations in northwest, Costa 


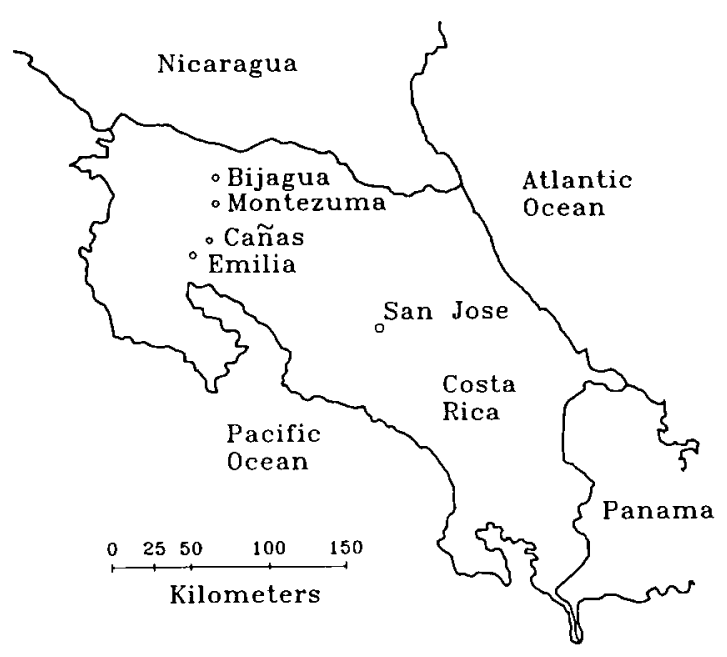

Fig. 1. Location of collecting sites in Costa Rica.

Rica (Fig. 1). La Emilia (EMILIA) is adjacent to the Enrique Jiminez Nunez Experiment Station, $21 \mathrm{~km} \mathrm{SW}$ of Cañas, Guanacaste Province. Flies were collected at the interface between a dry tropical forest and pasture with cattle present (elevation $\approx 20 \mathrm{~m}$ ). Finca Montezuma (MONTEZUMA) is $25 \mathrm{~km} \mathrm{NW}$ of Cañas. Collections were made at the interface between a tropical forest and a mature coffee field (elevation $500 \mathrm{~m}$ ). Finca Bedilla (BIJAGUA-l and BIJAGUA-2) was $3 \mathrm{~km}$ $\mathrm{N}$ of Bijagua, Alajuela Province (elevation 800 $\mathrm{m})$. The collecting site was on the edge of a small clearing in a wet tropical forest. Flies were collected with nets at feeding stations baited with rotting beef liver (Parker \& Welch 1992) and held in screen cages provisioned with honeywater for up to $8 \mathrm{~h}$ before being transported to the Enrique Jiminez Nuñez Experiment Station where identifications were confirmed. Flies were placed in liquid nitrogen for storage and transporting to the Midwest Livestock Insects Research Laboratory in Lincoln, NE, where they were transferred to a freezer maintained at $-80^{\circ}$ C. EMILIA, MONTEZUMA, and BIJAGUA-1 collections were made from 3-14 October 1992. BIJAGUA-2 was collected from 18 March to 28 April 1993. Ninty-three percent of the C. hominivorax and $63 \%$ of the C. macellaria collected were females. Pinned voucher specimens are in the Agricultural Research Service Screwworm Laboratory Collection at El Alto de Ochomogo, Cartago, Costa Rica. Heads and excess homogenate of flies examined are being maintained frozen $\left(-80^{\circ} \mathrm{C}\right)$ at the Midwest Livestock Insects Research Laboratory, Lincoln, NE, as biochemical voucher specimens and for use in future molecular genetics studies.

Electrophoretic Techniques. Polyacrylamide gel electrophoresis was used for this study. General procedures were similar to those of Munstermann $(1979,1980)$. Heads were removed from each fly and stored individually for other studies. Headless flies were ground in $150 \mu \mathrm{l}$ of grinding buffer ( $10 \%$ sucrose, $0.1 \%$ Triton X-100 [Sigma, St. Louis, MO], $0.37 \%$ EDTA, Bromophenol Blue and Mercaptoethanol in 1:5 dilute triscitrate [TC] buffer [ $19 \mathrm{mM}$ Trizma base, Sigma], $5.6 \mathrm{mM}$ citric acid, $\mathrm{pH} 7.1$ ).

Six percent acrylamide gels were prepared with 1:2 diluted TC and tris-borate-EDTA (TBE) $(81 \mathrm{mM}$ Trizma base, $28 \mathrm{mM}$ boric acid, $14.6 \mathrm{mM}$ EDTA, pH 8.9) buffers. Photo-Flo (0.5\%, [Kodak, Rochester, NY]) was added to the gels to improve staining and resolution (Green et al. 1990). Electrophoresis conditions were set at $300 \mathrm{~V}$ constant voltage for $3 \mathrm{~h}$ (TBE) or $4 \mathrm{~h}$ (TC) in a vertical slab gel unit (Hoeffer Scientific, San Francisco, CA). Initial currents were 0.027 (TBE) and 0.045 (TC) $\mathrm{mA}$ per gel and ending currents were 0.015 (TBE) and 0.039 (TC) $\mathrm{mA}$ per gel. Gels were 14 by $16 \mathrm{~cm}$ and $1.5 \mathrm{~mm}$ thick. To avoid overheating, buffer in the TC units was circulated between the upper and lower chambers.

Gels were presoaked in the appropriate staining buffer for $0.5 \mathrm{~h}$ to stabilize the $\mathrm{pH}$ before staining. Stain recipes were those of Murphy et al. (1990) except GCD and HADH (Green et al. 1990), AO (Steiner \& Josylin 1979), PHOS (Black \& Krafsur 1985) and TRE (Meredith 1980) (see Table 1 for enzyme systems). Gels were incubated at $37^{\circ} \mathrm{C}$ for $0.5 \mathrm{~h}$ before PMS (phenazine methosulfate) was added. NBT (nitro blue tetrazolium) was used in place of MTT (3-[4, 5-dimethylthiazol-2-yl]-2,5-diphenyltetrazolium bromide). ACOH and PGDH were stained simultaneously on the same gel. CAP was stained in tris-HCl pH 7.0 buffer. The most common allele in $C$. hominivorax for each locus was called the 100 allele. Additional alleles were assigned numerical names based on their migration relative to the 100 allele.

Thirty-nine enzyme systems were screened for C. hominivorax (Table 1). The 13 enzyme systems used for the population analysis (Table 2) were selected for their reliable staining and our confidence in interpretation of the banding patterns. Enzyme systems that were variable in $C$. hominivorax were given preference.

Statistical Analysis. BIOSYS-1 (Swofford \& Selander 1981) was used to compute population allele frequencies, expected and observed heterozygosities, test for fit with Hardy-Weinberg expectations, and calculate Nei's genetic distance (Nei 1978) and Wright's $F$ statistics (Wright 1978).

\section{Results}

Enzyme Systems. Five of the 39 enzyme systems examined, ALPH, GALDH, LDH, SDH, and SORDH did not stain. Five systems were inconsistent or too weak to score-ACPH, ADH, DDH, CAP, and SOD. DDH and CAP were vari- 
Table 1. Enzyme and buffer systems for C. hominivorax and C. macellaria

\begin{tabular}{|c|c|c|c|}
\hline Enzyme & Number $^{a}$ & Symbol $^{b}$ & Buffer \\
\hline Acid phosphatase & E. C. 3.1 .3 .2 & $\mathrm{ACPH}$ & TBE \\
\hline Aconitate hydratase & E. C. 4.2 .1 .3 & $\mathrm{ACOH}$ & $\mathrm{TC}$ \\
\hline Adenylate kinase & E. C. 2.7 .4 .3 & $\mathrm{AK}$ & TC \\
\hline Alcohol dehydrogenase & E. C. 1.1.1.1 & $\mathrm{ADH}$ & TC \\
\hline Aldehyde oxidase & E. C. 1.2 .3 .1 & $\mathrm{AO}$ & TBE \\
\hline Alkaline phosphatase & E. C. 3.1 .3 .1 & ALPH & TBE \\
\hline Aspartate transaminase & E. C. 2.6.1.1 & ATT & $\mathrm{TC}$ \\
\hline Cytosol aminopeptidase & E. C. $3.4 .1 \mathrm{I} .1$ & CAP & TC \\
\hline Dihydrolipoamide dehydrogenase & E. C. 1.8 .1 .4 & DDH & TC \\
\hline Esterase & E. C. 3.1.1.1 & $\mathrm{EST}$ & TBE \\
\hline Formaldehyde dehydrogenase & E. C. 1.2 .1 .1 & FDH & TBE \\
\hline Fructose-bisphosphatase & E. C. 3.1 .3 .11 & FBP & \\
\hline Fructose-biphosphate aldolase & E. C. 4.1 .2 .13 & ALD & TC \\
\hline Fumarate hydratase & E. C. 4.2 .1 .2 & FUMH & TC \\
\hline Galactose dehydrogenase & E. C. 1.1 .1 .48 & GALDH & \\
\hline Glucose dehydrogenase & E. C. 1.1 .1 .118 & GDH & \\
\hline Glutamate dehydrogenase & E. C. 1.4 .1 .2 & GLUD & TC \\
\hline Glyceraldehyde-3-phosphate dehydrogenase & E. C. 1.2 .1 .12 & GAPDH & TC \\
\hline Glycerol dehydrogenase & E. C. 1.1 .1 .72 & GCD & TC \\
\hline Glucose-6-phosphate dehudrogenase & E. C. 1.1 .1 .49 & G6PDH & TBE \\
\hline Glucose-6-phosphate isomerase & E. C. 5.3 .1 .9 & GPI & $\mathrm{TC}$ \\
\hline Glycerol-3-phosphate dehydrogenase & E. C. 1.1.1.8 & G3PDH & TC, TBE \\
\hline Hexokinase & E. C. 2.7 .1 .1 & HK & $\mathrm{TC}$ \\
\hline Hydroxyacid dehydrogenase & E. C. 1.1 .99 .6 & HADH & TC, TBE \\
\hline L-Iditol dehydrogenase & E. C. 1.1 .1 .14 & SORDH & \\
\hline Isocitrate dehydrogenase & E. C. 1.1 .1 .42 & IDH & TC \\
\hline Lactate dehydrogenase & E. C. 1.1 .1 .27 & $\mathrm{LDH}$ & \\
\hline Malate dehvdrogenase & E. C. 1.1 .1 .37 & $\mathrm{MDH}$ & TC \\
\hline Malate dehydrogenase $\left(\mathrm{NADP}^{+}\right)$ & E. C. 1.1 .1 .40 & MDHP & TBE \\
\hline Mannose-6-phosphate isomerase & E. C. 5.3 .1 .8 & MPI & TBE \\
\hline Octanol dehydrogenase & E. C. 1.1 .1 .73 & ODH & TC, TBE \\
\hline Phosphogluconate 2-dehydrogenase & E. C. 1.1 .1 .44 & PGDH & $\mathrm{TC}$ \\
\hline Phosphoglucomutase & E. C. 5.4 .2 .2 & $\mathrm{PGM}$ & TBE \\
\hline Phosphorylase & E. C. 2.4 .1 .1 & PHOS & $\mathrm{TC}$ \\
\hline Succinate dehydrogenase & E. C. 1.3 .99 .1 & $\mathrm{SIH}$ & \\
\hline Superoxide dismutase & E. C. 1.15 .1 .1 & SOD & \\
\hline$\alpha, \alpha$-Trehalase & E. C. 3.2 .1 .28 & TRE & TC, \\
\hline Triose-phosphate isomerase & E. C. 5.3 .1 .1 & TPI & TBE \\
\hline Xanthine dehydrogenase & E. C. 1.1 .1 .204 & $\mathrm{XDH}$ & TBE \\
\hline
\end{tabular}

${ }^{a}$ Nomenclature Committee International Union of Biochemistry 1984.

${ }^{b}$ Murphy et al. 1990.

able in $C$. hominivorax, and heterozygote banding patterns indicated monomeric structures. Up to four banding regions were observed for $\mathrm{ADH}$, three of which appeared to be variable; but con- sistent staining could not be achieved. In three systems, the bands were so diffuse that they could not be scored-AK, GPI, and PHOS. Eight enzyme systems (AAT, AO, EST, GDH, HK,

Table 2. Gene diversity at enzyme loci in C. hominivorax and C. macellaria

\begin{tabular}{|c|c|c|c|c|c|c|c|}
\hline \multirow{2}{*}{ Locus } & \multirow{2}{*}{$\begin{array}{l}\text { Subunit } \\
\text { structure }\end{array}$} & \multicolumn{3}{|c|}{ C. hominitorax } & \multicolumn{3}{|c|}{ C. macellaria } \\
\hline & & No. alleles & $\mathrm{H}_{o}{ }^{a}$ & $\mathrm{H}_{E}^{l}$ & No alleles & $\mathrm{H}_{0}{ }^{a}$ & $\mathrm{H}_{E}^{b}$ \\
\hline$\overline{\Lambda c o h}$ & Monomer & 4 & 0.038 & 0.038 & 5 & 0.184 & 0.191 \\
\hline Ald & & 1 & 0.000 & 0.000 & 1 & 0.000 & 0.000 \\
\hline$F d h$ & Dimer & 3 & 0.213 & 0.224 & 5 & 0.092 & 0.093 \\
\hline Fumh & Tetramer? & 2 & 0.007 & 0.007 & 2 & 0.007 & 0.007 \\
\hline Gapdh & & 1 & 0.000 & 0.000 & 2 & 0.004 & 0.004 \\
\hline Ged & Monomer & 3 & 0.244 & 0.268 & 7 & 0.429 & 0.446 \\
\hline$G 3 p d h$ & Dimer & 2 & 0.460 & 0.500 & 2 & 0.004 & 0.004 \\
\hline Hadh & Dimer & 3 & 0.453 & 0.464 & 5 & 0.188 & 0.179 \\
\hline$I d h$ & & 2 & 0.007 & 0.007 & 2 & 0.067 & 0.065 \\
\hline$M d h$ & Dimer & 4 & 0.028 & 0.028 & 4 & 0.025 & 0.025 \\
\hline$M p i$ & Monomer & 3 & 0.307 & 0.337 & 8 & 0.610 & 0.669 \\
\hline Pgdh & Dimer & 2 & 0.059 & 0.058 & 6 & 0.170 & 0.173 \\
\hline$P g m$ & Monomer & 3 & 0.010 & 0.010 & 5 & 0.223 & 0.229 \\
\hline Mean $\pm S E M$ & & $2.54 \pm 0.27$ & $0.141 \pm 0.048$ & $0.149 \pm 0.052$ & $4.31 \pm 0.62$ & $0.154 \pm 0.051$ & $0.160 \pm 0.055$ \\
\hline
\end{tabular}

"Observed heterozygosity.

${ }^{b}$ Expected heterozygosity based upon Hardy-Weinberg equilibrium. 
MDHP, TRE, and XDH) gave uninterpretable banding patterns. AO, GDH, MDHP, and XDH showed variable migration rates but did not appear to follow Mendelian inheritance. MDHP exhibited an unusual banding pattern, two strong bands with three evenly spaced weaker bands in between; this pattern was observed in both $C$. hominivorax and C. macellaria. AAT exhibited two loci, the faster migrating of which was variable in C. hominivorax. Crossing studies showed that the variability was of genetic origin, but the data were inconsistent. EST, HK, and TRE exhibited complicated banding patterns. Five or six EST loci were apparent and at least three were variable. Overlapping of the loci and inconsistent staining made the variable loci difficult to interpret. Three loci were observed for HK, one of which was variable but not interpretable. Several banding regions were visible on the TRE gels, the fastest migrating of which was highly variable in $C$. macellaria; this locus was blurred and could not be scored in $C$. hominivorax. Three enzyme systems, FBP, GLUD, and G6PDH, stained clearly and consistently but appeared to be fixed in C. hominivorax and were not included in the population survey. Two enzyme systems stained the same enzyme as another system; ODH resolved FDH, and TPI resolved G3PDH. Heterozygous banding patterns for variable loci indicated subunit structures (Table 2) consistent with those previously reported (Murphy et al. 1990).

Population Structure. In C. hominivorax, 11 of the 13 enzyme loci were variable and 5 of those were polymorphic using the 0.95 criteria (Table 3 ). In C. macellaria, 12 of the 13 loci were variable and 6 were polymorphic. Expected heterozygosity was 0.149 for $C$. hominivorax and 0.160 for $C$. macellaria (Table 2). Observed genotypes differed significantly from Hardy-Weinberg expectations (with pooling, see Swofford \& Selander [1981], $P<0.05)$ for two loci in $C$. hominivorax, Gcd in BIJAGUA-1 (excess homozygotes, $\left.\chi^{2}=4.362, d f=1, P=0.037\right)$ and $M p i$ in BIJAGUA-1 (excess heterozygotes, $\chi^{2}=$ 4.525, $d f=1, P=0.033$ ), BIJAGUA-2 (excess homozygotes, $\chi^{2}=5.376, d f=1, P=0.020$ ) and MONTEZUMA (excess homozygotes, $\chi^{2}=$ $4.917, d f=1, P=0.027)$ populations. No loci differed significantly from Hardy-Weinberg expectations in C. macellaria populations.

Wright's $F$ statistics (Table 4 ) suggest a small departure from random mating in both $C$. hominivorax and C. macellaria populations. The values for $F_{S T}$ indicate that geographic differentiation accounted for less than $1 \%$ of the genetic variability observed in both species.

Nei's genetic distances were $\leq 0.001$ (Table 5) for all of the within species comparisons. Genetic distances between $C$. hominivorax and $C$. macellaria were between 0.899 and 0.916 .

\section{Discussion}

Results of this study indicate that screwworm in northwest Costa Rica is a single panmictic species. This conclusion agrees with that of Krafsur \& Whitten (1993) for central Mexico but differs from that of Richardson et al. (1982) for Texas and Mexico. Geographic variation accounted for $<1 \%$ of the total amount of genetic variation present in these populations. Krafsur \& Whitten (1993) reported a larger $F_{I S}$ value for the central Mexican populations. They suggested that those values were probably caused by pooling of heterogeneous samples. Our results support this conclusion. Our samples were each collected over a short time period and sites within a locality were $<100 \mathrm{~m}$ apart. Consequently, our $F_{I S}$ value is much smaller, 0.065 versus 0.131 for the three loci $(G 3 p d h[=\alpha-G p d h], F d h[=O d h]$ and $P g m)$ reported by Krafsur \& Whitten. The $F_{I S}$ value observed in our study is probably the result of a high level of relatedness between screwworm collected within a short time frame. A female screwworm can lay $>400$ eggs in a single egg mass (Thomas \& Mangan 1989). Because the density of screwworms is low (Laake 1936), a given sample probably is made up of a small number of sibling groups. This conclusion is supported by the distribution of the $F d h_{66}$ allele in the MONTEZUMA population. Of the seven individuals carrying the $F d h_{66}$ allele, five were heterozygotes with the $F d h_{84}$ allele. Only 0.8 such heterozygotes were expected $(2 \times$ $0.12 \times 0.03 \times 116)$. It is nearly certain that these five individuals were siblings. Assuming that the parents of these flies were $F d h_{100} / F d h_{84}$ and $F d h_{100} / F d h_{66}$, the $5 F d h_{84} / F d h_{66}$ flies represent $25 \%$ of the progeny. Combined with the two $F d h_{100} / F d h_{66}$ individuals, the seven flies carrying the $F d h_{66}$ allele represent $50 \%$ of the progeny of this sibship. Therefore, 10 to $20 \%$ of the flies collected at this site were possibly from a single sibling group. Analysis of the mitochondrial DNA of these flies is necessary to confirm this interpretation.

Pooling our data for Costa Rica with those of Krafsur \& Whitten (1993) for central Mexico across the three loci studied by those authors resulted in $F_{I S}=0.11, F_{S T}=0.01$, and $F_{I T}=$ 0.12 . The large $F_{I S}$ and $F_{I T}$ values are undoubtedly caused by the Wahlund effect from pooling of the populations into three groups, Colima, Manzanillo and Costa Rica. The low value for $F_{S T}$ suggests that little genetic differentiation has occurred between screwworm populations from central Mexico and Costa Rica. Nei's genetic distances between the Costa Rican and the Mexican populations were 0.005-0.008. Comparing the frequencies of the most common alleles at the two enzyme loci studied by Whitten (1980) in Texas with our data from Costa Rica (G3pdh $h_{100}$ $\left[=\alpha \mathrm{GDH}^{1}\right], 0.686$ Texas versus 0.496 to 0.563 
Table 3. Allele frequencies for polymorphic isozyme loci in C. hominivorax and C. macellaria

\begin{tabular}{|c|c|c|c|c|c|c|c|c|}
\hline \multirow{2}{*}{ Locus } & \multirow{2}{*}{ Allele } & & C. ho & itorax & & & C. macello & \\
\hline & & BIJAGUA-I & BIJAGUA-2 & EMILIA & MONTEZUMA & BIJAGUA-I & EMILIA & MONTEZUMA \\
\hline Acoh, $n^{2}$ & & 48 & 100 & 23 & 116 & 107 & 92 & 83 \\
\hline & 60 & 0.01 & 0 & 0 & 0.009 & 0 & 0 & 0 \\
\hline & 80 & 0 & 0 & 0.065 & 0.017 & 0 & 0 & 0 \\
\hline & 100 & 0.990 & 0.995 & 0.935 & 0.974 & 0 & 0.005 & 0 \\
\hline & 108 & 0 & 0 & 0 & 0 & 0.005 & 0 & 0.006 \\
\hline & 112 & 0 & 0.005 & 0 & 0 & 0.047 & 0.038 & 0.048 \\
\hline & 116 & 0 & 0 & 0 & 0 & 0.070 & 0.043 & 0.042 \\
\hline & 120 & 0 & 0 & 0 & 0 & 0.879 & 0.913 & 0.904 \\
\hline$F d h, n^{a}$ & & 48 & 99 & 23 & 116 & 107 & 92 & 83 \\
\hline & 66 & 0 & 0 & 0.022 & 0.0 .30 & 0 & 0 & 0 \\
\hline & 84 & 0.073 & 0.111 & 0.174 & 0.116 & 0.009 & 0 & 0 \\
\hline & 100 & 0.927 & 0.889 & 0.804 & 0.853 & 0.019 & 0.022 & 0.018 \\
\hline & 105 & 0 & 0 & 0 & 0 & 0.009 & 0 & 0 \\
\hline & 114 & 0 & 0 & 0 & 0 & 0.930 & 0.962 & 0.970 \\
\hline & 132 & 0 & 0 & 0 & 0 & 0.033 & 0.016 & 0.012 \\
\hline Fumh, $n^{a}$ & & 48 & 100 & 23 & 116 & 107 & 92 & 83 \\
\hline & 60 & 0.010 & 0 & 0.022 & 0 & 0 & 0 & 0 \\
\hline & 100 & 0.990 & 1.000 & 0.978 & 1.000 & 0 & 0 & 0 \\
\hline & 106 & 0 & 0 & 0 & 0 & 1.000 & 0.989 & 1.000 \\
\hline & 153 & 0 & 0 & 0 & 0 & 0 & 0.011 & 0 \\
\hline Gapdh, $n^{a}$ & & 48 & 100 & 23 & 116 & 107 & 92 & 83 \\
\hline & 100 & 1.000 & 1.000 & 1.000 & 1.000 & 0.995 & 1.000 & 1.000 \\
\hline & 114 & 0 & 0 & 0 & 0 & 0.005 & 0 & 0 \\
\hline$G c d, n^{a}$ & & 48 & 100 & 23 & 116 & 107 & 92 & 83 \\
\hline & 36 & 0 & 0 & 0 & 0 & 0.042 & 0.033 & 0.030 \\
\hline & 47 & 0 & 0 & 0 & 0 & 0.028 & 0.016 & 0.012 \\
\hline & 53 & 0 & 0 & 0 & 0 & 0.009 & 0.011 & 0.006 \\
\hline & 64 & 0 & 0 & 0 & 0 & 0.715 & 0.750 & 0.675 \\
\hline & 77 & 0 & 0 & 0 & 0 & 0.009 & 0.022 & 0.012 \\
\hline & 86 & 0.115 & 0.170 & 0.109 & 0.168 & 0 & 0 & 0 \\
\hline & 90 & 0 & 0 & 0 & 0 & 0.192 & 0.168 & 0.265 \\
\hline & 100 & 0.885 & 0.830 & 0.870 & 0.828 & 0.005 & 0 & 0 \\
\hline & 116 & 0 & 0 & 0.022 & 0.004 & 0 & 0 & 0 \\
\hline$G 3 p d h, n^{a}$ & & 48 & 100 & 23 & 116 & 107 & 92 & 83 \\
\hline & 74 & 0.438 & 0.475 & 0.478 & 0.504 & 0.005 & 0 & 0 \\
\hline & 100 & 0.563 & 0.525 & 0.522 & 0.496 & 0.995 & 1.000 & 1.000 \\
\hline Hadh, $n^{a}$ & & 48 & 100 & 23 & 116 & 107 & 92 & 83 \\
\hline & 96 & 0 & 0 & 0 & 0 & 0.023 & 0.011 & 0.030 \\
\hline & 100 & 0.750 & 0.650 & 0.783 & 0.677 & 0 & 0 & 0 \\
\hline & 108 & 0 & 0 & 0 & 0 & 0.893 & 0.924 & 0.898 \\
\hline & 115 & 0.219 & 0.225 & 0.196 & 0.276 & 0 & 0 & 0 \\
\hline & $12 \tilde{5}$ & 0 & 0 & 0 & 0 & 0.065 & 0.060 & 0.030 \\
\hline & 130 & 0.031 & 0.125 & 0.022 & 0.047 & 0 & 0.005 & 0 \\
\hline & 142 & 0 & 0 & 0 & 0 & 0.019 & 0 & 0.042 \\
\hline$I d h, n^{n}$ & & 48 & 100 & 23 & 116 & 107 & 92 & 8.3 \\
\hline & 100 & 0.979 & 1.000 & 1.000 & 1.000 & 0.977 & 0.978 & 0.940 \\
\hline & 117 & 0.021 & 0 & 0 & 0 & 0.023 & 0.022 & 0.060 \\
\hline$M d h, n^{a}$ & & 48 & 100 & 23 & 116 & 107 & 92 & 83 \\
\hline & 59 & 0 & 0 & 0 & 0 & 0.005 & 0 & 0 \\
\hline & 73 & 0 & 0 & 0.022 & 0.004 & 0 & 0 & 0 \\
\hline & 92 & 0 & 0 & 0 & 0 & 0.986 & 0.995 & 0.982 \\
\hline & 100 & 0.990 & 1.000 & 0.935 & 0.983 & 0 & 0 & 0 \\
\hline & 109 & 0 & 0 & 0 & 0 & 0.005 & 0 & 0.006 \\
\hline & 114 & 0 & 0 & 0 & 0 & 0.005 & 0.005 & 0.006 \\
\hline & 121 & 0 & 0 & 0 & 0 & 0 & 0 & 0.006 \\
\hline & 130 & 0.010 & 0 & 0.022 & 0.013 & 0 & 0 & 0 \\
\hline & 158 & 0 & 0 & 0.022 & 0 & 0 & 0 & 0 \\
\hline$M p i, n^{a}$ & & 48 & 100 & 23 & 116 & 107 & 92 & 83 \\
\hline & 91 & 0 & 0.035 & 0 & 0.009 & 0 & 0 & 0 \\
\hline & 94 & 0 & 0 & 0 & 0 & 0 & 0.005 & 0.006 \\
\hline & 100 & 0.760 & 0.775 & 0.848 & 0.806 & 0 & 0 & 0 \\
\hline & 108 & 0.240 & 0.190 & 0.152 & 0.185 & 0.173 & 0.130 & 0.163 \\
\hline & 112 & 0 & 0 & 0 & 0 & 0.033 & 0.054 & 0.006 \\
\hline & 124 & 0 & 0 & 0 & 0 & 0.112 & 0.076 & 0.139 \\
\hline & 140 & 0 & 0 & 0 & 0 & 0.477 & 0.582 & 0.518 \\
\hline & 160 & 0 & 0 & 0 & 0 & 0.187 & 0.125 & 0.114 \\
\hline & 180 & 0 & 0 & 0 & 0 & 0.009 & 0.011 & 0.018 \\
\hline & 192 & 0 & 0 & 0 & 0 & 0.009 & 0.016 & 0.036 \\
\hline Pgm, $n^{a}$ & & 48 & 100 & 23 & 116 & 107 & 92 & 83 \\
\hline & 85 & 0 & 0 & 0 & 0 & 0.005 & 0 & 0 \\
\hline & 94 & 0 & 0 & 0 & 0 & 0.009 & 0.022 & 0 \\
\hline & 91 & 0 & 0.005 & 0.022 & 0.004 & 0.037 & 0.033 & 0.018 \\
\hline & 100 & 0.969 & 0.980 & 0.957 & 0.966 & 0.902 & 0.897 & 0.928 \\
\hline & 108 & 0.031 & 0.015 & 0.022 & 0.030 & 0.047 & 0.049 & 0.048 \\
\hline & 114 & 0 & 0 & 0 & 0 & 0 & 0 & 0.006 \\
\hline$P g d h, n^{a}$ & & 48 & 100 & 23 & 116 & 107 & 92 & 83 \\
\hline & 60 & 0 & 0.010 & 0 & 0.004 & 0 & 0 & 0 \\
\hline & 100 & 1.000 & 0.990 & 1.000 & 0.996 & 0.009 & 0.022 & 0.018 \\
\hline & 117 & 0 & 0 & 0 & 0 & 0.864 & 0.848 & 0.916 \\
\hline & 133 & 0 & 0 & 0 & 0 & 0.019 & 0.011 & 0.006 \\
\hline & 142 & 0 & 0 & 0 & 0 & 0.089 & 0.109 & 0.048 \\
\hline & 167 & 0 & 0 & 0 & 0 & 0.014 & 0.011 & 0.012 \\
\hline & 186 & 0 & 0 & 0 & 0 & 0.005 & 0 & 0 \\
\hline
\end{tabular}

a Number of individuals examined from each population. 
Table 4. Wright (1978) F statistics for C. hominivorax and C. macellaria populations

\begin{tabular}{|c|c|c|c|c|c|c|}
\hline \multirow{2}{*}{ Locus } & \multicolumn{3}{|c|}{ C. hominivorax } & \multicolumn{3}{|c|}{ C. macellaria } \\
\hline & $F_{I S}$ & $F_{S T}$ & $F_{I T}$ & $F_{I S}$ & $F_{s r}$ & $F_{I T}$ \\
\hline Acoh & -0.048 & $0.025^{*}$ & -0.022 & 0.032 & 0.002 & 0.035 \\
\hline$F d h$ & 0.130 & $0.015^{*}$ & 0.143 & -0.003 & 0.005 & 0.002 \\
\hline Fumh & -0.018 & 0.010 & -0.008 & -0.011 & 0.007 & -0.004 \\
\hline Gapdh & & & & -0.005 & 0.003 & -0.002 \\
\hline Ged & 0.069 & 0.006 & 0.075 & 0.033 & 0.006 & 0.039 \\
\hline G3pdh & 0.096 & 0.002 & 0.098 & -0.005 & 0.003 & -0.002 \\
\hline Hadh & -0.030 & 0.012 & -0.017 & -0.058 & 0.004 & -0.054 \\
\hline$I d h$ & -0.021 & $0.016^{*}$ & -0.005 & -0.046 & 0.009 & -0.036 \\
\hline$M d h$ & -0.036 & $0.019^{*}$ & -0.016 & -0.010 & 0.002 & -0.008 \\
\hline$M p i$ & 0.034 & 0.007 & 0.040 & 0.074 & $0.007^{*}$ & 0.080 \\
\hline$P g m$ & -0.030 & 0.003 & -0.027 & 0.014 & 0.002 & 0.016 \\
\hline Pgdh & -0.008 & 0.005 & -0.004 & 0.010 & $0.007^{*}$ & 0.017 \\
\hline Mean & 0.045 & 0.009 & 0.053 & 0.029 & 0.006 & 0.035 \\
\hline
\end{tabular}

${ }^{*} F_{S T}<>0, P<0.05, \chi^{2}=2 \mathrm{~N}\left(F_{S T}\right)(\mathrm{k}-1)$ for $\mathrm{k}$ alleles (see Table 2) and s populations (C. hominivorax $=4$, C. macellaria $=$ 3) with $(\mathrm{k}-1)(\mathrm{s}-1)$ df. $F_{I T}<>0, P<0.05, \chi^{2}=\left(F_{I T}\right)^{2} \mathrm{~N}(\mathrm{k}-1)$ with $\mathrm{k}(\mathrm{k}-1) \mathrm{df}$.

Costa Rica, and $P g m_{100}\left[=\mathrm{PGM}^{2}\right], 0.964$ Texas versus 0.957 to 0.980 Costa Rica) indicates a moderate level of similarity between these populations as well.

Richardson et al. (1982) proposed that screwworm in Texas and Mexico was a complex of reproductively isolated gamodemes based on cytological and isozyme data. These authors identified eleven types of screwworm, many of which occurred sympatrically. Because of the success of the screwworm eradication program (Graham 1985, Vargas-Teran 1991), none of the populations studied by Richardson can be further analyzed. Makela \& Richardson (1978) predicted an even greater number of cryptic species in southern Mexico and southward. Our data from three climatologically diverse locations in Costa Rica show no evidence of reproductively isolated populations of screwworm. Furthermore, based on the allozyme loci studied by Whitten (1980) and Krafsur \& Whitten (1993), screwworm populations in Costa Rica are genetically similar to those from Texas and central Mexico.

The population structure of $C$. macellaria is similar to that of $C$. hominivorax. Heterozygosity and percentage of the loci polymorphic are slightly higher in C. macellaria and the mean number of alleles per locus is much higher (Table 2). $F_{I S}$ is lower in C. macellaria than $C$. hominivorax. This is probably because the higher density of $C$. macellaria reduces the probability of collecting siblings. Higher genetic variability is expected in a species that exploits a variable environment than one restricted to a narrower, well-defined environment (Powell 1971, Hedrick et al. 1976). Although small, the differences observed between C. macellaria and C. hominivorax support this contention.

Nei's genetic distances between C. macellaria and $C$. hominivorax were in the order of 0.9 . This level of genetic divergence is characteristic of well-differentiated, nonsibling species (Ayala et al. 1974) and suggests a time of divergence of 17-24 million years before present (Sarich 1977, Carlson et al. 1978). This predates the arrival of the modern mammalian faunas of North and South America (Stehli \& Webb 1985). Cochliomyia hominivorax and C. macellaria probably diverged during the Miocene and C. hominivorax evolved its parasitic behavior on the nowextinct faunas of that period in North or South America.

The five-banded pattern for the MDHP enzyme system in screwworm is unusual. Calyptrate Diptera have two loci coding the MDHP enzyme and consequently express a two-banded pattern (Black \& Krafsur 1985, Jones et al. 1987, Krafsur \& Black 1992). The five-band pattern was

Table 5. Nei's unbiased genetic distances for $C$. hominivorax and $C$. macellaria

\begin{tabular}{|c|c|c|c|c|c|c|c|}
\hline Location & 1 & 2 & 3 & 4 & 5 & 6 & 7 \\
\hline \multicolumn{8}{|c|}{ C. hominivorax } \\
\hline $\begin{array}{l}1 \text { Bijagua-1 } \\
2 \text { Bijagua-2 } \\
3 \text { Emilia } \\
4 \text { Montezuma }\end{array}$ & $* * * * *$ & $\begin{array}{l}0.000 \\
* * * * *\end{array}$ & $\begin{array}{l}0.000 \\
0.001 \\
* * * * *\end{array}$ & $\begin{array}{l}0.000 \\
0.000 \\
0.000 \\
* * * * *\end{array}$ & $\begin{array}{l}0.902 \\
0.899 \\
0.899 \\
0.906\end{array}$ & $\begin{array}{l}0.913 \\
0.909 \\
0.909 \\
0.916\end{array}$ & $\begin{array}{l}0.912 \\
0.909 \\
0.910 \\
0.916\end{array}$ \\
\hline \multicolumn{8}{|c|}{ C. macellaria } \\
\hline $\begin{array}{l}5 \text { Bijagua } \\
6 \text { Emilia } \\
7 \text { Montezuma }\end{array}$ & & & & & $* * * * *$ & $\begin{array}{l}0.000 \\
* * * * *\end{array}$ & $\begin{array}{l}0.000 \\
0.001 \\
* * * * * *\end{array}$ \\
\hline
\end{tabular}


observed consistently in 10 species of Calliphoridae encompassing the subfamilies Chrysomyiinae, Calliphorinae and Mesembrinellinae (unpublished data). MDHP is a tetramer (Murphy et al. 1990). The banding pattern expected for a heterozygous tetrameric enzyme is five evenly spaced bands. The most logical explanation for the five-banded pattern observed in the calliphorids is the formation of heterotetramers by subunits produced by the two MDHP loci. The reduced staining intensity of the intermediate bands would indicate that the heterotetramers either form at a lower rate than the homotetramers or that they have reduced activity under the staining conditions used. The uniformity of this phenomena in calliphorids and its absence in several muscid species (Black \& Krafsur 1985, Jones et al. 1987, Krafsur \& Black 1992) suggests that this pattern may be a useful apomorphy distinguishing the calliphorids as a group. Species from other families within the superfamily Oestroidea need to be examined to determine the extent of this phenomenon.

Proper and consistent nomenclature for allozyme loci is extremely important, especially with recent attempts to homologize loci across species (Heckel 1993). In this study, two enzyme systems stained the same enzyme as another system. FDH and ODH are clearly the same enzyme in screwworm. This phenomena has been observed in marine bivalves (Manchenko 1990) and humans (Hur \& Edenberg 1992, Koivusalo et al. 1989). The human enzyme has been characterized and classified as FDH (Hur \& Edenberg 1992, Koivusalo et al. 1989). We found the FDH stain to give much stronger and consistent bands than did the ODH stain. We recommend that this locus be recognized as $F d h$. TPI resolved the same enzyme as G3PDH. This was probably caused by incomplete conversion of the $\alpha$-glycerophosphate to dihydroxyacetone phosphate in the first step of the stain reaction.

\section{Acknowledgments}

We thank Frank Parker and Robert Fischel for assistance in collecting screwworms in Costa Rica; the owners and managers of Finca Bedilla, La Emilia, and Finca Montezuma for permission to collect on their properties; and Troy Heller for technical assistance. Elliot Krafsur kindly made available raw data from his previous work in central Mexico. John Foster, Elliot Krafsur, Leonard Munstermann, Steve Skoda, and C. J. Whitten provided helpful suggestions and critical reviews of the manuscript. This work was done in cooperation with the Institute of Agriculture and Natural Resources, University of Nebraska, Lincoln, NE, and is published as Journal Series, Nebraska Agricultural Research Division paper 10572.

\section{References Cited}

Ayala, F. J., M. L. Tracey, D. Hedgecock \& R. C. Richmond. 1974. Genetic differentiation during the speciation process in Drosophila. Evolution 28: 576-592.

Black, W. C. \& E. S. Krafsur. 1985. Electrophoretic analysis of genetic variability in the house fly (Musca domestica L.). Biochem. Genet. 23: 193203.

Brody, A. L. \& E. F. Knipling. 1943. Can larvae of Cochliomyia americana C. \& P. mature in carcasses? J. Parasitol. 29: 59-60.

Bush, G. L. \& R. W. Neck. 1976. Ecological genetics of the screwworm fly, Cochliomyia hominivorax (Diptera: Calliphoridae) and its bearing on the quality control of mass-reared insects. Environ. Entomol. 5: 821-826

Carlson, S. S., A. C. Wilson \& R. D. Maxson. 1978. Do albumin clocks run on time? A reply. Science (Washington, DC) 200: 1183-1185.

Cushing, E. C. \& W. S. Patton. 1933. Studies on the higher Diptera of medical and veterinary importance. Cochliomyia americana, sp. nov., the screwworm fly of the New World. Ann. Trop. Med. Parasitol. 27: 539-551.

Dear, J. P. 1985. A revision of the New World Chrysomyini (Diptera: Calliphoridae). Rev. Bras. Zool. 3: $109-169$.

Graham, O. H. 1985. Symposium on eradication of the screwworm from the United States and Mexico. Misc. Publ. Entomol. Soc. Am. 62: 1-68.

Green, C. A., R. F. Gass, L. E. Munstermann \& V. Baimai. 1990. Population-genetic evidence for two species in Anopheles minimus in Thialand. Med. Vet. Entomol. 4: 25-34.

Guimaraes, J. H., N. Papavera \& A. P. do Prado. 1983. As miiases na regiao neotropical (identifacacao, biologia, bibliografia). Rev. Bras. Zool. 1: 239-416.

Hall, D. G. 1948. The blowflies of North America. Thomas Say Foundation, Entomol. Soc. Am., Lanham, MD.

Heckel, D. G. 1993. Comparative genetic linkage mapping in insects. Annu. Rev. Entomol. 38: 381408.

Hedrick, P. W., M. E. Ginevan \& E. P. Ewing. 1976. Genetic polymorphism in heterogeneous environments. Annu. Rev. Ecol. Syst. 7: 1-32.

Hur, M. W. \& H. J. Edenberg. 1992. Cloning and characterization of the ADH5 gene encoding human alcohol dehydrogenase-5, formaldehyde dehydrogenase. Gene 121: 305-311.

Jones, C. J., R. S. Patterson \& D. E. Milne. 1987. Electrophoretic comparisons of isozymes from selected populations of Stomoxys calcitrans (Diptera: Muscidae). J. Med. Entomol. 24: 54-60.

Knipling, E. F. \& B. V. Travis. 1937. Relative importance and seasonal activity of Cochliomyia americana C. \& P. and other wound-infesting blowflies, Valdosta, Ga., 1935-1936. J. Econ. Entomol. 30: 727-735.

Koivusalo, M., M. Baumann \& L. Uotila. 1989. Evidence for the identity of glutathione-dependent formaldehyde dehydrogenase and class III alcohol dehydrogenase. FEBS Lett. 257: 105-109.

Krafsur, E. S. \& W. C. Black IV. 1992. Analysis of isozyme loci in the face fly, Musca autumnalis DeGeer. Biochem. Genet. 30: 625-634.

Krafsur, E. S. \& C. J. Whitten. 1993. Breeding structure of screwworm fly populations (Diptera: Calliphoridae) in Colima, Mexico. J. Med. Entomol. 30: $477-480$. 
J. E. Novy. 1987. crewworm eradication in North and Central America. Parasitol. Today 3: 131-137.

Laake, E. W., E. C. Cushing \& H. E. Parish. 1936. Biology of the primary screwworm fly, Cochliomyia americana, and a comparison of its stages with those of C. macellaria. U.S. Dep. Agric. Tech. Bull. 500.

Makela, M. E. \& R. H. Richardson. 1978. Hidden, reproductively isolated populations: one of nature's countermeasures to genetic pest control, pp. 49-66. In R. II. Richardson [ed.], The screwworm problem, evolution of resistance to biological control. University of Texas Press, Austin.

Manchenko, G. P. 1990. The use of allozymic patterns in genetic identification of enzymes. Isozyme Bull. 23: 102.

Meredith, S. E. O. 1980. A stain for the location of trehalase after electrophoresis in starch gels. Ann. Trop. Med. Parasitol. 74: 475.

Munstermann, L. E. 1979. Isozymes of Aedes aegypti: phenotypes, linkage, and use in the genetic analysis of sympatric subspecies populations in East Africa. Ph.D. dissertation, University of Notre Dame, Notre Dame, IN.

1980. Distinguishing geographic strains of the Aedes atropalpus group (Diptera: Culicidae) by analysis of enzyme variation. Ann. Entomol. Soc. Am. 73: 699-704.

Murphy, R. W., J. W. Sites, Jr., D. G. Buth \& C. H. Haufler. 1990. Proteins I: isozyme electrophoresis, pp. 45-126. In D. M. Hillis and C. Moritz [eds.], Molecular Systematics. Sinauer, Sunderland, MA.

Nei, M. 1978. Estimation of average heterozygosity and genetic distance from a small number of individuals. Genetics 89: 583-590.

Nomenclature Committee International Union of Biochemistry. 1984. Enzyme nomenclature. Academic, New York.

Parker, F. D. \& J. B. Welch. 1992. Monitoring adult populations of the screwworm (Diptera: Calliphoridae) with feeding stations baited with liver. J. Econ. Entomol. 85: 1740-1753.

Powell, J. R. 1971. Genetic polymorphisms in varied environments. Science (Washington, DC) 174 : $1035-1036$.
Rawlins, S. C. \& A. Mansingh. 1987. A review of ticks and screwworms affecting livestock in the Caribbean. Insect Sci. Appl. 8: 259-267.

Richardson, R. H., J. R. Ellison \& W. W. Averhoff. 1982. Autocidal control of screwworms in North America. Science (Washington, DC) 215: 361-370.

Sarich, V. M. 1977. Rates, sample sizes, and the neutrality hypothesis for electrophoresis in evolutionary studies. Nature (Lond.) 265: 24-28.

Snow, J. W., C. J. Whitten, A. Salinas, J. Ferrer \& W. H. Sudlow. 1985. The screwworm (Cochliomyia hominivorax) (Diptera: Calliphoridae) in Central America and proposed plans for its eradication south to the Darien Gap in Panama. J. Med. Entomol. 22: 353-360.

Stehli, F. G. \& S. D. Webb. 1985. The great American biotic interchange. Plenum, New York.

Steiner, W. W. M. \& D. J. Joslyn. 1979. Electrophoretic techniques for the genetic study of mosquitoes. Mosq. News 39: 35-53.

Swofford, D. L. \& R. B. Selander. 1981. BIOSYS-1: a FORTRAN program for the comprehensive analysis of electrophoretic data in population genetics and systematics, release 1.7. J. Hered. 72: 281-283.

Thomas, D. B. \& R. L. Mangan. 1989. Oviposition and wound-visiting behavior of the screwworm fly, Cochliomyia hominivorax (Diptera: Calliphoridae). Ann. Entomol. Soc. Am. 82: 526-534.

Vargas-Teran, M. 1991. The New World screwworm in Mexico and Central America. World Anim. Rev. October: 28-35 (special issue)

Whitten, C. J. 1980 . Use of the isozyme technique to assess the quality of mass-reared sterile screwworm flies. Ann. Entomol. Soc. Am. 73: 7-10.

Wright, S. 1978. Evolution and the genetics of populations, vol. 4. Variability within and among natural populations. University of Chicago Press, Chicago.

Received for publication 17 February 1994; accepted 17 May 1994 